\title{
Peningkatan Kemampuan Menulis Cerita Menggunakan Metode Picture And Picture Pada Siswa Madrasah Ibtidaiyah
}

\author{
Fatchur Rachman \\ UIN Prof. KH. Saifuddin Zuhri, Purwokerto, Indonesia \\ mbahweng00@gmail.com \\ Abdul Wachid BS. \\ UIN Prof. KH. Saifuddin Zuhri, Purwokerto, Indonesia \\ abdulwachidbs@iainpurwokerto.ac.id
}

\begin{abstract}
The purpose of this study is to improve the ability to write stories in students of Madrasah Ibtidaiyah (MI). This research was conducted at MIM Pangempon using picture and picture as the method. The research conducted is in the form of classroom action research or commonly abbreviated as CAR. This research is divided into two cycle stages, each stage of this cycle consists of planning, implementing actions, observing, and reflecting. As the subject in the classroom action research, the 4th grade students of MIM Pangempon, Kejobong District, Purbalingga Regency with a total of 10 students. Based on the results of this study, a conclusion can be drawn that learning to write stories for fourth grade students at MI Muhammadiyah Pangempon uses the picture method. and picture can improve students' abilities. This increase can be proven from the results obtained by students, namely before the action was $40 \%$, then in the first cycle it increased to $60 \%$, and in the second cycle it increased again to $90 \%$.
\end{abstract}

Keywords: Story Writing; Picture And Picture; Improvement 


\begin{abstract}
Abstrak
Tujuan dari penelitian ini berguna untuk meningkatkan kemampuan menulis cerita pada peserta didik madrasah ibtidaiyah (MI). Penelitian ini dilaksanakan di MIM Pangempon dengan mempergunakan picture and picture sebagai metodenya. Penelitian yang dilakukan berbentuk penelitian tindakan kelas atau yang lazim disingkat dengan PTK. Penelitian ini terbagi dalam dua tahap siklus, setiap tahapan siklus ini terdiri atas perencanaan, pelaksanaan tindakan, observasi, serta refleksi. Sebagai subjek dalam penelitian tindakan kelas yang dilakukan ialah siswa kelas 4 MIM Pangempon, Kecamatan Kejobong, Kabupaten Purbalingga dengan jumlah siswa sebanyak 10. Berdasarkan hasil pada penelitian ini dapat ditarik sebuah kesimpulan bahwa pembelajaran menulis cerita pada siswa kelas IV di MI Muhammadiyah Pangempon dengan menggunakan metode picture and picture dapat meningkatkan kemampuan siswa. Peningkatan ini dapat dibuktikan dari hasil yag diperoleh siswa yaitu sebelum tindakan $40 \%$, kemudian pada siklus I meningkat menjadi 60\%, dan pada siklus II meningkat lagi menjadi $90 \%$.
\end{abstract}

Kata kunci: penulisan cerita, picture and picture, peningkatan.

\title{
Pendahuluan
}

Peran penting guru dalam proses pembelajaran adalah harus mampu mengembangkan dan meningkatkan perubahan tingkah laku siswa sesuai tujuan belajar itu sendiri. (Bloom dan Krathwohl 2009, 15) menyatakan bahwa ada tiga ranah yang dapat dijadikan dasar dalam merumuskan tujuan pembelajaran yaitu ranah pengetahuan atau kognitif, ranah sikap atau afektif, dan psikomotorik atau kemampuan ketrampilan. Maka dari itu guru harus berusaha mengembangkan ketiga aspek tersebut dalam pembelaran agar dapat membentuk kepribadian individu siswa yang baik.

Salah satu tempat pengalaman pertama guru dapat membentuk kepribadian siswa adalah Madrasah Ibtidaiyah (MI). Berkaitan dengan hal tersebut, guru diharapkan dapat membimbing dan membekali anak didiknya dengan kepribadian yang baik, kemampuan berfikir yang baik pula serta kemampuan keterampilan dasar yang cukup agar siswa siap pada belajar pada tingkatan yang lebih tinggi karena pelajaran ini adalah salah satu mata pelajaran yang diberikan dari tingkatan dasar sampai tinggi. Dalam pembelajaran bahasa Indonesia juga tentu harus ada upaya-upaya untuk memunculkan serangkaian keterampilan siswa. Keterampilan ini juga tentu saling berhubungan dengan konsep dasar atau cara berfikir. Jika seseorang itu baik dalam berfikir maka tentu akan baik pula atau semakin terampil berbicaranya atau sebaliknya, jika cara berfikirnya baik maka akan berbicara dengan baik. Ada empat komponen berbahasa menurut Tarigan 
(2008) yaitu keterampilan untuk menyimak, keterampilan untuk berbicara, keterampilan untuk membaca, dan yang terakhir adalah keterampilan untuk menulis, dari keempat komponen keterampilan berbahasa ini pasti akan saling berkaitan.

Kegiatan menulis merupakan salah satu materi yang penting pada jenjang sekolah dasar atau madrasah ibtidaiyah. Menulis juga merupakan satu komponen dari empat ketrampilan berbahasa yang harus dikuasai oleh peserta didik. Mulyati (2008) menjabarkan menulis ialah suatu proses berpikir dan kemudian menuangkan pikiran tersebut kedalam bentuk wacana. Senada dengan yang disampaikan oleh Mulyati, (Widyamartaya 1990,9) juga mengungkapkan mencipta adalah seluruh rangkaian kegiatan dalam menuangkan gagasan dan menyampaikannya melalui tulisan agar dapat dipahami oleh pembaca. Kemampuan menulis cerita adalah salah suatu kompetensi menulis yang menjadi salah satu tujuan pembelajaran di jenjang sekolah dasar atau madrasah ibtidaiyah, dimana siswa diharapkan dapat mengungkapkan dan menuangkan perasaanya, ide dan gagasan terhadap orang lain melalui kegiatan menulis. Berkaitan dengan hal tersebut seyogyanya keterampilan menulis harus dibiasakan dan ditingkatkan sedini mungkin karena jika kemampuan menulis tidak dilatih dan dibiasakan dari kecil bukan tidak mungkin kemampuan tersebut akan menurun, tidak berkembang bahkan bisa saja hilang.

Berangkat dari penjabaran di atas kondisi di MIM Pangempon Kecamatan Kejobong Kabupaten Purbalingga belum menunjukan kondisi yang ideal. berdasarkan wawancara yang peneliti lakukan dengan guru kelas empat, didapatkan informasi bahwa kemampuan menulis siswa kelas IV di MIM Pangempon tahun pelajaran 2019/2020 masih rendah. Fakta ini diperkuat dengan hasil evaluasi dari pembelajaran menulis cerita masih banyak peserta didik belum sampai pada KKM yang ditentukan yakni pada nilai 65. Hasil yang diperoleh adalah sebanyak 6 dari 10 siswa masih mendapatkan nilai di bawah KKM, sedangkan 4 diantaranya telah melampaui. Hal ini disebabkan karena dalam menulis cerita siswa banyak yang tidak urut atau melompat dari alur satu ke alur yang lain, maka dari itu ide pokoknya pun masih belum terlihat dan tidak adanya keteraturan yang logis. Realita yang terjadi ini menunjukan belum berhasilnya guru dalam membimbing siswa dalam materi menulis cerita, sehingga guru ditunut agar dapat melakukan dan mengembangkan proses belajar mengajar yang kreatif dan inovatif agar tercapainya suatu tujuan pembelajaran.

Berdasarkan permasalahan di atas, diperlukan upaya untuk memperbaiki kondisi tersebut. Salah satu upaya adalah dengan memilih metode yang tepat. Suyono \& Hariyanto ( 2011:11) menjelaskan bahwa teknik pengajaran atau sering disebut dengan metode pembelajaran merupakan serangkaian perencanaan yang disusun secara runtut mulai dari rencana pembelajaran,langkah-langkah dalam pembelajaran,dan evaluasi 
yang akan digunakan. Salah satu metode pembelajaran yang digunakan untuk mewujudkan keterampilan menulis cerita di sekolah dasar atau madrasah ibtidaiyah ialah dengan menggunakan metode picture and picture.

Peneliti berupaya mendeskripsikan tentang Penelitian Tindakan Kelas (PTK) yang dilaksanakan oleh MIM Pangempon terkait penggunaan metode picture and picture dengan kajian yang relevan dengan penelitian sebelumnya. Berdasarkan penelusuran penulis, ada beberapa penelitian yang hampir semakna dengan penelitian yang penulis lakukan. Pertama, bersumber pada penelitian Ni Nyoman Ayu Sukarini (I Nyoman Jampel \& I Nyoman Jampira, 2015), Universitas Pendidikan Ganesha Singaraja, Indonesia dengan judul "Penerapan Metode Picture and Picture Berbantuan Media Gambar Untuk Meningkatkan Perkembangan Berbahasa Anak Kelompok B”. Riset ini fokus pada peran guru dalam pengelolaan pendidikan untuk peningkatan efektivitas pembelajaran yang sesuai. Kedua,hasil penelitian dari Yasi (Sri Kartikowati\& Hardisem, 2016) yang berjudul "Penggunaan Metode Picture And Picture Untuk Meningkatkan Minat Belajar Ilmu Pengetahuan Sosial Siswa Kelas Iv SDN 022 Sintong Kecamatan Tanah Putih Kabupaten Rokan Hilir”. Penelitian ini menjelaskan sebuah kesimpulan bahwa media gambar seri mampu meningkatkan kemampuan aktivitas guru dan siswa didalam melaksanakan pembelajaran dikelas.Ketiga,bersumber pada penelitian Istiqomah (Nur Karim\& Abdul, 2018) yang berjudul "Penggunaan Media Gambar Seri Untuk Meningkatkan Kemampuan Menulis Karangan Sederhana Dalam Pembelajaran Bahasa Indonesia Siswa Kelas V SD Islam NU Pungkuran”. Penelitian ini menjelaskan sebuah kesimpulan bahwa media gambar seri mampu meningkatkan kemampuan siswa dalam menulis karangan sederhana.

Berdasarkan hasil dari pemaparan kajian penelitian sebelumnya tentang Penelitian Tindakan Kelas (PTK) diatas maka dijabarkan oleh penulis dan diperoleh rumusan masalah yaitu, "Apakah dengan menggunakan metode picture and picture kemampuan menulis cerita pada siswa kelas IV MI Muhammadiyah Pangempon tahun pelajaran 2019/2020 dapat meningkat?”. Adapun tujuan penelitian ini meningkatkankemampuan menulis cerita pada siswa kelas IV MI Muhammadiyah Pangempon tahun pelajaran 2019/2020 menggunakan metode picture and picture.

\section{Pembahasan}

Jenis penelitian ini ialah Penelitian Tindakan Kelas. Penelitian ini meliputi beberapa langkah, langkah yang digunakan oleh peneliti ,diantaranya yaitu: rancangan penelitian, tindakan, observasi. dan penilaian proses serta hasil pelaksanaan tindakan tersebut,dan langkah yang terakhir adalah refleksi dari setiap tahapan yang di lakukan 
sampai dihasilkan peningkatan atau perbaikan yang di tandai dengan meningkatnya hasil belajar murid sesuai dengan KKM atau Kriteria Ketuntasan Minimal yang ada pada MI tersebut.

Kajian dari penelitian ini menggunakan teknik pengamatan atau observasi,dan wawancara mendalam serta pemberian tes atau ujian. Validitas data di cocokan dengan menggunakan Teknik trianggualsi data yaitu guru dan murid. Analisis data yang diterapkan dalam penelitian ini ialah teknik analisis deskriptif. Teknik analisis data deskriptif ini diterapkan guna mengungkap berbagai macam kelebihan dan kekurangan cara kerja guru dan murid dalam suatu proses pembelajaran dan membandingkan pencapaian hasil yang dicapai di tiap-tiap siklus. Hasil analisis ini dijadikan sebagai dasar untuk menyusun rencana tindakan untuk tahap selanjutnya.

\section{Metode Pembelajaran Picture and Picture}

Metode picture and picture adalah metode belajar dengan memanfaatkan media gambar yang dipasangkan atau dijodohkan dengan urutan yang nyata dan benar. Maka sebelum melaksanakan pembelajaran, guru harus menyediakan gambar-gambar yang akan diberikan kepada siswa baik dalam bentuk kartu ataupun mepergunakan media pembelajaran dengan basis teknologi informasi dan komunikasi seperti power point.(Sahrudin \& Sri Iriani, 2009).

\section{Meningkatkan Kemampuan Menulis}

Peneliti memilih untuk menggunakan metode ini dengan melakukan observasi pendahuluan atau awal sebagai upaya untuk mengetahui situasi dan kondisi lapangan, yaitu di Madrasah Ibtidaiyah Muhammadiyah Pengempon atau MIM Pangempon. Pada observasi pendahuluan didapatkan siswa-siswi kelas IV sedang malaksankan kegiatan pembelajaran Bahasa Indonesia tentang menulis cerita, selanjutnya peneliti melakukan wawancara dengan responden yang terdiri dari guru dan siswa. Dari kegiatan observasi awal tersebut dapat diketahui realitas nyata yang berlangsung pada saat proses pembelajaran mata pelajaran Bahasa Indonesia dengan pokok bahasan menulis cerita di Kelas IV MIM Pangempon terdapat masalah dalam menulis cerita.

Data yang didapatkan oleh peneliti pada observasi pendahuluan adalah para siswa terlihat pasif dan belum memiliki ketrampilan yang baik dalm menulis cerita. Kompetensi siswa dalam materi menulis cerita sangatlah rendah apabila dibandingkan dengan ketrampilan lainya dalam pelajaram bahasa Indonesia seperti menyimak, membaca, dan bercerita. Berangkat dari fakta tersebut peneliti memutuskan untuk melakukan kolaborasi dengan guru kelas IV MIM Pangempon untuk memperbaiki kondisi pembelajaran menulis cerita. Berdasarkan hasil diskusi dan curah ide dengan 
guru menyepakati untuk melakukan tindakan kelas berupa perbaikan metode pembelajaran. Metode yang dipilih guna memberbaiki masalah yang ada adalah dengan menerapkan metode pembelajaran picture and picture pada materi menulis cerita mapel Bahasa Indonesia.

Selanjutnya peneliti bekerjasama dengan guru kelas membuat suatu rencana pembelajaran (RPP) dimana metode picture and picture dipilih pada penerapaan tindakan pada siklus pertama. Tindakan di siklus pertama merupakan tindakan awal untuk meningkatkan hasil belajar dengan menggunakan metode ini. Berdasarkan analisa hasil pengamatan yang telah didapatkan pada siklus pertama, ternyata tampakbeberapa kelemahan. Pada siklus pertama kelemahan yang ada berasal dari segi guru dan siswa.

Masih kurangnya ketrampilan guru dalam mengelola kelas merupakan fakta yang didapatkan pada segi guru, yaitu guru melaksanakan kegiatan yang belum sesuai dengan Rencana Pembelajaran yang dibuat. Adapun dari segi siswa diperoleh fakta bahwa sisa-sisi kelas IV MIM Pangempon dalam pembelajaran menulis certa terliat memiliki yang rendah hal ini ditandai dengan sikap pasif serta tidak antusias saat mengikuti proses pembelajaran. Akibatnya pembelajaran berjalan dengan sangat monoton dan tidak menarik dan hasil belajar yang didapatkan oleh para siswa rendah belum sesuai dengan target criteria ketuntasan minimal atau KKM yang telah ditentukan.

Secara umum para siswa belum memiliki keseriusan dalam mengikuti materi yang disampaikan oleh guru. Bercanda dan melakukan aktifitas sendiri-sendiri masih mewarnai kegiatan siswa selama proses belajar mengajar. Setelah melakukan analisa informasi dari fakta yang telah didapatkan peneliti sedikit menyimpulkan, bahwa peserta didik masih menemui kendala untuk menguasai pembelajaran menulis cerita.Selanjutnya, guna mengatasi kelemahan serta kekurangan yang terlihat pada pelaksanaan siklus I maka dilaksanakanlah siklus II.

Sebelum memulai siklus II peneliti dan guru melakukan diskusi dan curah pendapat terkait dengan langkah-langkah yang akan diambil pada siklus II. Dari diskusi tersebut diperoleh hasil berupa kesepakatan solusi yang harus dilakukan oleh guru guna memperbaiki proses pembelajaran pada siklus I. Solusi yang disepakati berupa memperbaiki pengaturan kelas, memberikan motivasi pada para siswa, serta melakukan pendalaman meteri sebagai upaya meningkatakan ketrampilan menulis cerita siswa.

Selanjutnya setelah dilaksaksanakan silkus II, dibandingkan dengan siklus I terlihat peningkatan ketrampilan siswa dalam menulis cerita. Siklus II adalah tahapan terakhir dalam penelitan ini. Pada siklus II ini guru berusaha mengurangi kelemahan serta kekurangan selama proses pembelajaran ini. Picture and picture diterapkan Pada 
siklus II oleh guru. Siklus II digunakan untuk menguatkan hasil pada siklus pertama, selanjutnya dapat diambil kesimpulan yaitu metode pembelajaran picture and picture dapat meningkatkan kemampuan siswa dalam menulis cerita pada siswa kelas IV MIM Pangempon.

Hasil belajar yang pada siklus pertama terlihat ada 6 anak yang melampaui batas KKM. Pada siklus kedua ini meningkat menjadi 9 siswa yang melampaui batas nilai KKM 1 siswa sesuai dengan batas nilai KKM dan hanya 1 siswa yang belum mencapai batas nilai KKM, sehinhha dapat dikatakan hamper semua siswa telah mencapai KKM. Dengan fakta ini dapat disimpulkan bahwa metode picture and picture berhasil meningkatkan hasil belajar siswa pada pelajaran bahasa Indonesia materi menulis cerita.

Penggunaan picture and picture dalam penelitian tindakan kelas ini, ternyata berhasil membatu siswa dalam ketrampilan menulis cerita yang ditandai dengan semakin meningkatmya ketrampilan siswa dalam mencurahkan ide dan gagasannya melalui kosa kata menjadi cerita.Motivasi dan antusiasme siswa dalam mengikuti pembelajaran juga menjadi lebih baik, hal ini ditandai dengan banyak dan seringnya siswa mengajukan pertanyaan pada guru begitupula dalam menjawab pertanyaan dari guru, selain itu para siswa sangat antusias dalam menyelesaikan tugas-tugas yang diberikan oleh guru.

Hasil akhir dari palaksaan siklus pertama dan siklus kedua memberikan gambaran kesimpulan bahwa pada penelitian tidakan kelas kali ini memberikan dampak yang positif berupa peningkatan kemampuan pengajar dalam hal pengelolaan kelas. Serta dapat disimpulkan pula bahwa metode pictureand picture dapat dimanfaatkan oleh para guru sebagai salah satu pilihan metode pembelajaran yang dapat dipilih dalam upaya meningkatkan siswa untuk lebih aktif dalam mengikuti proses pembelajaran khususnya pelajaran Bahasa Indonesia pada meteri menulis cerita

Berikut penulis sajikan tabel hasil belajar pada setiap siklus yang telah dilakukan: 
Fatchur Rachman dan Abdul Wachid BS.

Tabel 1. Data tabel hasil belajar pada setiap siklus

\begin{tabular}{|c|c|c|c|c|c|c|}
\hline \multirow{2}{*}{ No } & \multirow{2}{*}{ Nama } & \multirow{2}{*}{ KKM } & \multicolumn{3}{|c|}{ Hasil Evaluasi } & \multirow{2}{*}{ Ket. } \\
\hline & & & Pra Siklus & Siklus I & Siklus II & \\
\hline 1 & Khafi Fauzan Hafidz & 65 & 65 & 75 & 80 & Naik \\
\hline 2 & Gita Dwi Lestari & 65 & 60 & 65 & 70 & Naik \\
\hline 3 & Jani Aolia Khatifah & 65 & 65 & 70 & 80 & Naik \\
\hline 4 & Satriyo & 65 & 70 & 80 & 90 & Naik \\
\hline 5 & Khayla Maharani & 65 & 60 & 65 & 70 & Naik \\
\hline 6 & Melani Oktavia & 65 & 40 & 50 & 50 & Tetap \\
\hline 7 & Adit Prayoko & 65 & 50 & 60 & 70 & Naik \\
\hline 8 & Erina yuliani & 65 & 70 & 80 & 85 & Naik \\
\hline 9 & Nur Aisyiah & 65 & 60 & 60 & 65 & Naik \\
\hline \multirow[t]{7}{*}{10} & Bahrun & 65 & 60 & 60 & 65 & Naik \\
\hline & Nilai Terendah & & 40 & 50 & 50 & \\
\hline & Nilai Tertinggi & & 70 & 80 & 90 & \\
\hline & $\mathrm{KKM} \leq 65$ & & 6 & 4 & 8 & \\
\hline & $\mathrm{KKM} \geq 65$ & & 4 & 6 & 1 & \\
\hline & Total Nilai & & 600 & 665 & 725 & \\
\hline & Nilai Rata-rata & & 60 & 66,5 & 72,5 & \\
\hline
\end{tabular}

Sumber: Analisis Data

\section{Simpulan}

Setelah dilakukan kegiatan penelitian dalam seluruh siklus, penulis mengambil kesimpulan yaitu pembelajaran dengan menggunakan metode picture and picture efektif dalam meningkatkan kemampuan menulis cerita pada siswa di kelas IV MI Muhammadiyah Pangempon. Hal ini ditandai dengan nilai kemapuan menulis cerita yang meningkat pada setiap siklus yang telah dilakukan. Ada tiga saran yang dapat peneliti sampaikan, diantaranya sebagai berikut: (1) Metode picture and picture dapat dipilih oleh guru sebagai alternatif metode pembelajaran bahasa Indonesia dalam materi menulis cerita. (2) Para guru hendaknya meningkatkan profesionalitas pedagogiknya sehingga dapat mengajar secara lebih baik dalam berkreasi dan berinovasi dalam memilih metode pembelajaran, pemanfataan media pembelajaran, serta dapat mengembangkan bahan ajar sehingga pembelajaran berjala dengan 
menyenangkan. (3) Melatih siswa untuk terbiasa dalam menulis sehingga siswa menjadi lebih terampil dalam mengeksplor ide-idenya.

\section{DAFTAR PUSTAKA}

A’la, M. (2011). Quantum Teaching. Jogjakarta : Diva Press.

Arikunto. (2008). Penelitian Tindakan Kelas. Bumi Aksara.Jakarta

Abbas, S. (2006). Pembelajaran Bahasa Indonesia yang Efektif di Sekolah Dasar.

Istiqomah, N., \& Karim, A. (2018). Penggunaan Media Gambar Seri Untuk Meningkatkan Kemampuan Menulis Karangan Sederhana Dalam Pembelajaran Bahasa Indonesia Siswa. Seminar Nasional Pendidikan, Sains Dan Teknologi Fakultas Matematika Dan Ilmu Pengetahuan Alam Universitas Muhammadiyah Semarang, $1-13$. https://jurnal.unimus.ac.id/index.php/psn12012010/article/download/3316/3149

Kanisius. Widyamartaya. (1990). Seni Menuangkan Gagasan, Yogyakarta:

Mulyati, Y. (2008). Keterampilan Berbahasa Indonesia SD. Jakarta: Universitas Terbuka.

Nurudin. (2010). Dasar - Dasar Penulisan. Malang : UMM Press.

Palguna, P. N. D., Garminah, N. N., \& Sudana, D. N. (2015). Penerapan metode picture and picture berbantuan media gambar untuk meningkatkan perkembangan berbahasa anak Kelompok B. E-Journal PGSD, 3(1), 11-25.

Pribadi, B. A. (2009). Model Desain Sistem Pembelajaran. Jakarta : Dian Rakyat.

Rugiyem, 2011. Penggunaan Metode Picture and Picture Untuk Meningkatkan Minat Belajar Siswa Kelas IV SDN 004 Lingkar Naga Buatan II Kecamatan Kota Gosib Kabupaten Siak. Skripsi Program Study Pendidikan Ekonomi FKIP-UNRI Pekanbaru.

Sahrudin \&Iriani, S. (2011). Model Pembelajaran Picture and Picture. Diperoleh 14 Februari 2012.

Suyono \& Hariyanto. 2011. Belajar dan Pembelajaran. Bandung: PT. Remaja Rosdakarya.

Tarigan, H. G. (2008). Menulis Sebagai Suatu Keterampilan Berbahasa. Bandung : Angkasa.

Yasi, (2016). Penggunaan Metode Picture and Picture Untuk Meningkatkan Minat Belajar Ilmu Pengetahuan Sosial Siswa Kelas Iv Sdn 022 Sintong Kecamatan Sosial Siswa Kelas Iv Sdn 022 Sintong Kecamatan. 1-12. 
Fatchur Rachman dan Abdul Wachid BS.

Y, M. (2008). Keterampilan Berbahasa Indonesia SD. Universitas Terbuka. 